\title{
CHAPTER 1 \\ SIX COMMON MISTAKES \\ IN SELLING A BUSINESS TO AN UNRELATED THIRD PARTY
}

This chapter and all subsequent chapters up through Chapter 8 assume that each of the alternatives to sale (Chapters 9-13) have been explored and none of these alternatives are practical for the business. Accordingly, the business must be sold to an unrelated third party.

The unrelated third party may be someone in the same business (a strategic buyer), a pure private equity fund, or a hybrid private equity fund which includes an existing portfolio business to which they wish to "bolt" the business.

The following are six of the most common mistakes made by businesses in attempting to sell the business to an unrelated third party:

- Failing to resolve "deal killers" before the exit date;

- Poor timing of the exit;

- Lack of audited financial statements;

- Failure to minimize working capital;

- Failing to create positive and negative incentives for key employees;

- Failure to discuss the exit decision with the family members.

Six more common mistakes are discussed in the next chapter. 


\section{Failing to Resolve "Deal Killers"}

The following are three examples of common "deal killers" discussed in this chapter:

- Tax problems must be resolved well before the projected exit date. A common problem in businesses is an inventory cushion. Other common tax problems include payments to family members for services which exceed the reasonable value of those services and the use of company property, products or services by family members without reasonable compensation. Each of these activities may constitute a disguised gift, potentially subject to gift tax, or a disguised dividend, which was improperly deducted for income tax purposes.

- Environmental issues must be addressed and resolved.

- Other business risk issues which must be resolved include, but are not limited to, such issues as employee misclassification as independent contractors which results in a violation of both tax and labor laws.

\section{Resolve Tax Issues Well Before Exit Date}

Outstanding tax risks can prevent the owner from selling the business and may take many years to resolve. For example, assume that the business has a so-called "inventory cushion." The existence of a material inventory cushion can prevent an auditor from providing an audit opinion on the financial results of operations. Without an audit opinion, many potential buyers will be turned off since these buyers will not have the comfort of the opinion of an independent auditor and may not be able to obtain financing to pay the purchase price.

Moreover, the business entity (assuming it is not a tax flow-through entity) will have tax liability for the inventory cushion, together with interest and penalties. This is a major risk. Again, potential buyers may be turned off by this risk, thereby lowering the sale value of the business, assuming it is at all saleable. Even if the business corporation is a tax flow-through entity (such as a Subchapter S corporation or a limited liability company), that entity could have potential liability because of failing to provide correct tax information to the equity owners. 
Payments to other family members or others which exceed the reasonable value of their services will also create tax risks for a potential buyer. To the extent that these payments are really disguised gifts or dividends, these payments will not be deductible for federal or state income tax purposes or may result in gift tax. If these disguised gifts or dividends are material, potential buyers will likely lose any incentive to bid for the business or will require a substantial escrow at the closing of the sale.

To resolve these tax issues may take several years and require amending previously filed federal and state income tax returns. If the business owner fails to anticipate these tax issues, they may find that they are really unable to sell the business when the time is right.

\section{Environmental Issues}

Another turn-off for potential buyers is the existence of material violations of federal, state or local environmental laws. It may be very difficult for a potential buyer to quantify the cost of an environmental remediation. As a result, the buyer may well require such a significant escrow at closing that it may make the net purchase price to the selling equity holders unattractive.

It may take years to actually remediate the environmental problems of the business. Accordingly, it is important for the owner of the business to start the remediation process well before the expected target date for a sale. The remediation should start with a Phase I and Phase II (if required) environmental study by a reputable environmental firm. In some cases, environmental insurance may be available.

\section{Independent Contractors}

Another common tax risk is the use of so-called "independent contractors" who may in reality be employees. Potential buyers may walk away as a result of the failure to withhold income tax from these so-called "independent contractors" if the liability is material. Likewise, the business may be liable for the failure to pay overtime and other violations of labor laws. 


\section{Poor Timing of the Exit}

It is important to understand the primary drivers of the valuation of the business and to time the sale process to coincide with a period of high valuations. We can divide the valuation drivers into two categories: macro factors, such as the state of the economy and the industry, and micro factors which relate to the peculiar aspects of the business such as revenues, business prospects, etc.

The best way of getting a low value for the business is to sell it when either the macro factors concerning both the economy and the industry or are poor or when the micro factors are unattractive.

\section{Macro Factors}

The macro factors affecting the valuation of the business refer to whether the economy is in an upward cycle or depressed. Macro factors also include the state of the industry or industries in which the business operates.

For example, no matter how well the business was performing in 2009 (the "micro factors"), this was a bad year to sell the business because of the macro economic factors affecting the entire economy and very few sales were consummated. The value of the business during a recession is typically significantly lower than the value of the business during prosperity. The business may, from a micro point of view, be doing well in a recession. Nevertheless, the valuations will tend to be depressed if the economy is not doing well.

During a recession, banks and other financial institutions will typically lend less money to financial buyers. During a prosperous economy, a bank might be willing to lend close to five times earnings before interest, taxes and depreciation/amortization (EBITDA) to a financial buyer. However, during a recession, that same bank might lower the multiplier of EBITDA to three. This has the effect of lowering the valuation which will be placed by the financial buyer on the business.

Even strategic buyers will tend to have a lower valuation for a business during a recession unless there are unusual synergies.

A key to maximizing the sale price is to sell at a time when there is the maximum number of potential buyers. It is important to time the sale 
so that there are financial buyers available to compete with any strategic buyers. Financial buyers are most likely to be available when the banks and other financial institutions from which they borrow have the most generous lending terms and afford them the largest amount of leverage in making the purchase. If there are a significant number of potential financial and strategic buyers, this will enable the owner to conduct an auction, which typically will give the business the highest possible sale price, as discussed below.

The macro factors relating to the industry in which the business operates are also extremely important. If the industry is viewed as being in a decline, that decline will also adversely depress the value of the business. Potential buyers who use either a discounted cash flow method of valuation will tend to creating higher risk discount figure, thereby adversely affecting the value of the business. Potential buyers who use the multiplier of EBITDA method of business valuation will likewise place a lower multiplier of EBITDA during the period that the industry is in decline. The lower EBITDA multiplier means that the business will be worth less.

\section{Micro Factors}

The best time to sell a business is when the business is doing well and its prospects are excellent. Many owners of businesses tend to panic when business is poor and do not attempt to correct the problems of the business. Obviously, there are times when the problems cannot be corrected and selling the business at a depressed price is better than bankruptcy.

As noted in the Introduction, it is important for the business owners to understand how the businesses will be valued and the specific factors affecting the valuation. This can be accomplished by obtaining a valuation of the business from an independent valuation firm as early as 5 years before any projected exit date. However, there are specific factors which can affect the valuation as described in the attached chart from my book entitled Valuing the Business: Strategies to Maximize the Sale Price (John Wiley \& Sons, Inc., 2005). 
FACTORS THAT INFLUENCE VALUATION

Factors Increasing Valuation

1. Strong customer relationships at all levels.

2. Proprietary products or services.

3. No single customer accounts for more than $5 \%$ of revenues or profits.

4. Strong management team (important mainly to financial buyers).

5. Excellent employee turnover and relations.

6. Consistent revenue and earnings trends.

7. Plant and equipment in good repair.

8. Intellectual property assets which are legally protected.
Factors Decreasing Valuation

1. Weak customer relationships and frequent turnover.

2. Lack of proprietary products or services.

3. A single customer accounts for over $15 \%$ of revenues or profits.

4. A weak management team (so-called one-man-show syndrome).

5. Poor employee turnover and relations.

6. Inconsistent revenue and earnings trends.

7. Plant or equipment has been neglected and requires significant repairs.

8. Lack of legally protected intellectual property assets.

The adverse micro factors noted in this table should be corrected, to the extent possible, well before the projected exit date for the business.

\section{Lack of Audited Financial Statements}

Many businesses believe that they save substantial money by obtaining from their accounting firm only a compilation opinion or a review opinion, but not an audit opinion, on the business' financial statements. Whatever savings that may have been achieved by not obtaining an audit opinion will typically be more than offset at the time of an exit.

When the business only uses a compilation opinion on its financial statements, this is viewed by potential buyers as merely a mathematical exercise and provides no assurance whatsoever to the potential buyer.

Even a review opinion of the financial statements is far less assurance to the potential buyer of the accuracy of the financial statements and their compliance with generally accepted accounting principles ("GAAP"). A business will typically pay much less for a compilation opinion than a review opinion and far less than the cost of an audit opinion. 
The lack of audited financial statements may mean that certain buyers, usually financial buyers, may not even bid for the business. This is particularly true for financial buyers who may not be able to obtain debt financing for their purchase price without audited financial statements. In an auction of the business, which typically produces the highest price, potential buyers may not want to spend the funds necessary to obtain audited financial statements and may refuse to bid.

The lack of audited financial statements also increases the likelihood that the equity owners of the business which has been sold will have liability after the sale closing. Almost all purchase agreements for a business will require either the business entity or the equity owners, or both, to make the following representation and warranty:

\begin{abstract}
"The Financial Statements are complete and correct in all material respects and have been prepared in accordance with generally accepted accounting principles applied on a consistent basis throughout the periods indicated and with each other. The Financial Statements accurately set out and describe the financial condition of the Company as of the dates, and for the periods, indicated therein."
\end{abstract}

The equity owners of the business should want the comfort of its accounting firm giving assurance that this warranty and representation is correct. Only an audit opinion from the accounting firm typically provides this assurance.

\title{
Failure to Minimize Working Capital
}

Business owners will typically be permitted to remove from the business excess working capital prior to the closing of the sale. In some cases, the sale proceeds can be significantly enhanced by this excess working capital.

A typical buyer will attempt to attain a figure for the amount of necessary or "normalized" working capital for the business. In many cases the buyer will review the financial statements for several years before the agreement of sale is executed to obtain a base figure for necessary working capital to be left in the business after the closing. Any amount 
above this base or "normalized" working capital figure would then be considered excess working capital which can be removed by the business owners before the closing.

It is therefore important for the business to minimize the amount of working capital with which it conducts business several years before the proposed exit date. This will permit the owners to maximize the amount that is considered to be "excess" working capital. Working capital can be minimized by a variety of techniques including minimization of inventory and faster collection of accounts receivable from customers, among other methods.

\section{Failing to Create Positive and Negative Incentives for Key Employees}

Potential buyers will want to speak to the company's key employees (family or otherwise) prior to signing any agreement of sale as part of their due diligence. Therefore, the owner's decision to sell the business will be brought to the attention of this group of persons at some point in the process.

It is important that these key employees be given the incentive to help promote the sale. If they are not given incentives, their natural tendency will be to become concerned about their job security and their future with the company.

Moreover, these key employees will begin to think about the full implication of the decision to sell and the effect it will have upon their lives and their futures. This may cause them to think about other possible alternatives for their careers. Keep in mind that whatever bond the owner may have created with these key employees, through chemistry or leadership, may change once the decision to sell becomes known.

The incentives to key employees of the business must be both affirmative and negative:

- affirmative, in order to align the employees' interest with the owners in the implementation of the sale;

- negative, in order to disincentivize key employees from leaving or becoming potential competitors. 
The affirmative incentives usually consist of some form of termination bonus equal to a meaningful percentage of the key employee's base salary. Typically, anywhere from $50 \%$ to $100 \%$ of the base salary should be paid. The bonus should be payable only in the event of sale.

This affirmative cash incentive can be created immediately before the potential buyer commences its due diligence with these key employees. Other types of affirmative incentives may be implemented earlier. One example would be a stock option granted to the key employee at an early point in time that could be exercised only in the event the company is sold or goes public, a so-called "exit event stock option."

The disadvantage of a cash termination bonus equal to a percentage of base salary is that in the year of sale, the earnings of the business are reduced by the amount of the bonus. This reduction may or may not be important to the buyer.

A cash termination bonus is simpler to implement than an exit event stock option plan and should be used in situations where the reduction in the year-of-sale earnings is not material or is unimportant to the buyer.

Negative incentives to key employees could take the form of an agreement not to compete or, preferably, not to solicit customers or engage in other hostile acts in relationship to the company. It may not be possible to obtain this type of agreement on the eve of the sale of the company, as it requires a voluntary act by the employees to execute such a non-competition or non-solicitation agreement and possibly some special consideration under state law to make it enforceable. Therefore, it is necessary to obtain a non-competition or non-solicitation agreement from key employees several years before the exit decision and preferably when the employees are hired.

Non-solicitation of customer agreements are much more easily obtained and enforced than non-competition agreements. To make such a non-competition or non-solicitation agreement enforceable, the company should seek counsel from attorneys specializing in this area. Many state laws require some form of special consideration to be given to the employee for this purpose if the agreement is signed during the course of employment. For example, in some states, the company might be able to implement this type of agreement at the same time the company is implementing its normal salary increases or bonuses. 
The length of time of the non-competition or non-solicitation agreement should be kept sufficiently short so that there is no difficulty in having a court enforce it. Typically, 1 year is sufficient to protect a buyer and will usually be enforceable if the geographic scope of the limitation is reasonable under the circumstances. Non-competition or non-solicitation agreements protect the seller prior to a sale and facilitate a sale to a potential buyer.

Another alternative is to work out a severance plan for employees that requires them not to compete with the company or solicit customers during the period of the severance payments. Severance payments to lessimportant employees can be limited to 1 or 2 weeks, whereas the payments to key employees can last as long as 1 or 2 years. Severance payments can be expensive and therefore should be limited to a period sufficient to permit the company or the buyer to cement a new relationship with customers handled by a key employee. Typically, 1 year is sufficient.

\section{Failure to Discuss the Exit Decision with Family Members}

In the case of a family business, it is important to involve other family members, particularly those active in the business, in the exit decision. This should be accomplished at an early point in time.

As I stated in my book The Family Business Guide, the decision to sell a family business is gut-wrenching for many families. Families tend to identify the business with themselves and view the loss of the business similar to the death of a close relative. The emotional value of owning a family business cannot be underestimated. ${ }^{1}$ Family meetings with frank and open discussions are essential to maintaining family harmony in anticipation of a sale.

It has been said that family businesses succeed when dreams of the subsequent generations are integrated with the dreams of the family. ${ }^{2}$ It has also been suggested that there are more CEOs in family businesses

\footnotetext{
${ }^{1}$ Thomas M. Zellweger and Joseph H. Astrachan, "On the Emotional Value of Owning a Firm," Family Business Review (2008) Vol. 21, p. 347.

${ }^{2}$ Edward Monte, a therapist and family business consultant, as quoted in Shel Horowitz, "Father and Sons, Mothers and Daughters," Family Business Center, University of Massachusetts Amherst (http://www.umass.edu/fambiz/articles/successors/fathers_ sons.html).
} 
with lost personal dreams than in any other type of business. ${ }^{3}$ Open discussions of exit planning within the family tend to identify potential CEOs and their aspirations. It also helps to prevent lawsuits.

In many family businesses, other family members are beneficiaries of trusts established as part of the owner's estate plan and these trusts typically contain stock or other equity of the business. The owner may be the trustee of these trusts. The author was involved in one sale of a family business in which the trust beneficiary sued the trustee (his uncle) for breach of the trustee's fiduciary duty in selling the business and attempted to enjoin the sale of the business. Although the author's law firm was successful in defeating the suit, it is preferable to have clauses in these trust documents which discourage such lawsuits. For example, a clause in the trust instrument requiring the trust beneficiary to pay the legal fees of the trustee for any unsuccessful lawsuit would be helpful in discouraging litigation. Although the trust clause might not be enforceable in all jurisdictions, its very existence has a deterrent effect.

It would soften the discussion of an exit decision with family members if there were some reward for them. The reward could take the form of a family limited partnership, a grantor retained annuity trust (a so-called "GRAT"), an installment sale to an intentionally defective grantor trust (a so-called "IGDT"), or some outright gifts. It is beyond the scope of this book to discuss these wealth transfer mechanisms in detail. However, they are discussed in Chapter 11 of my book entitled The Family Business Guide.

The next chapter discusses six more common mistakes.

${ }^{3} I d$. 